\title{
Modifikasi Media Bola Abu Kayu Bakar Untuk Meningkatkan Hasil Pembelajaran Tolak Peluru Gaya Ortodoks
}

\author{
Sofyan Lutfi Aziz ${ }^{1}$, Andy Widhiya Bayu Utomo ${ }^{2}$ \\ 1,2 Sekolah Tinggi Keguruan dan Ilmu Pendidikan Modern Ngawi
}

* Corresponding Author. E-mail: ${ }^{1}$ sofyan9698@gmail.com ${ }^{2}$ andystkipmodern@gmail.com

\begin{abstract}
Receive: $13 / 07 / 2021$
Accepted: $23 / 07 / 2021$

Published: 04/10/2021

Abstrak

Penelitian ini bertujuan untuk meningkatkan hasil belajar tolak peluru gaya otodoks di MTs Terpadu Al Firdaus Kedunggalar Kelas VII C mata pelajaran Pendidikan Jasmani Olahraga dan Kesehatan yang menggunakan media bola abu kayu bakar. Metode penelitian ini adalah Penelitian Tindakan Kelas (PTK) yang dilakukan sebanyak dua siklus dengan jumlah 24 siswa. Penelitian ini dilaksanakan pada semester genap tahun ajaran 2020/2021. Teknik pengumpulan data yang dilakukan oleh peneliti yaitu melalui observasi, dan tes. Pada tindakan siklus I pembelajaran tolak peluru gaya ortodoks siswa yang (tuntas) hanya 11 siswa (45,8\%) sementara yang tidak tuntas sebanyak 13 siswa (54,1\%) secara umum rata-rata mendapat nilai 68 (tidak tuntas). Melihat analisis data tersebut sehingga peneliti melanjutkan di siklus II, pada siklus II siswa memperoleh nilai rata-rata 80 (tuntas), siswa yang tuntas sebanyak 22 (91,6\%) dan yang tidak tuntas 2 siswa (8,3\%), secara umum siswa sudah memenuhi Kriteria Ketuntasan Minimal (KKM) yaitu 75. Sehingga penggunaan media bola abu kayu bakar terbukti mampu meningkatkan pembelajaran tolak peluru gaya ortodoks hal ini sesuai yang diharapkan oleh peneliti sehingga peneliti. Peneliti berharap media ini dapat membantu kepada seluruh guru Pendidikan Jasmani terutama materi tolak peluru.
\end{abstract}

Kata Kunci: peningkatan tolak peluru gaya ortodoks, media bola abu kayu bakar, penggunaan media bola abu kayu bakar

\section{Abstract (English-Indonesia)}

This study aims to improve the learning outcomes of autodox-style shot put at MTs Terpadu Al Firdaus Kedunggalar Class VII C subjects of Physical Education, Sports and Health using firewood ash ball as the media. This research method is Classroom Action Research (CAR) which was conducted in two cycles with a total of 24 students. This research was conducted in the even semester of the 2020/2021 academic year. Data collection techniques carried out by researchers are through observation, and tests. In the action of the first cycle of orthodox style shot put learning, only 11 students (45.8\%) did complete, while 13 students (54.1\%) did not complete, on average, they scored 68 (incomplete). Looking at the data analysis, the researcher continued in the second cycle, in the second cycle the students got an average score of 80 (completed), 22 students (91.6\%) who completed and 2 students (8.3\%) did not complete. In general, students have met the Minimum Completeness Criteria (KKM) which is 75 . So the use of firewood ash ball media is proven to be able to improve orthodox style shot put learning. The researcher hopes that this media can help all Physical Education teachers, especially the bullet put material.

Keywords: improvement of orthodox style shot put, firewood ash ball media, use of firewood ash ball media

\section{Pendahuluan}

Pendidikan merupakan proses belajar manusia sejak lahir sampai menjelang hayatnya melalui berbagai ilmu pengetahuan dalam bentuk pengajaran yang bertahap dimana proses pengajaran menjadi tanggung jawab orang tua, guru, dan masyarakat (Asnaldi et al., 2018). Pendidikan suatu usaha menumbuhkan manusia dan mengembangkan potensi baik secara jasmani dan rohani sesuai dengan nilai-nilai yang ada didalam kebudayaan dan masyarakat (Fadlih, 2019).

Pendidikan jasmani dapat di artikan sebagai salah satu bagian yang tidak dapat dipisahkan dari dunia pendidikan pada umumnya terutama dalam di Sekolah Menengah Pertama (SMP), dikarenakan pendidikan jasmani memiliki tujuan untuk membentuk fisik, mengembangkan keterampilan, berfikir kritis, membentuk karakter displin, dan meningkatkan kesehatan.

Pendidikan jasmani merupakan Komponen dari pendidikan yang tidak terpisahkan yang di gunakan untuk mengembangkan kemampuan melalui gerakan gerakan yang sesuai dengan tujuan pendidikan yang diharapkan yaitu mencakup pengetahuan, keterampilan, dan sikap (Mustafa \& Dwiyogo, 2020). Dalam hal ini guru sangat berperan aktif dalam memotivasi siswa dalam hal perkembangan motorik, kemampuan fisik, pengetahuan dan menanamkan pola hidup sehat dalam kehudupan sehari hari yang bertujun untuk merangsang pertumbuhan dan perkembangan yang seimbang. 
Pendidikan jasmani mempunyai peran yang sangat penting dalam mepercepat proses penyelenggaraan pendidikan yang merupakan proses pembinaan manusia secara terus menerus dan berlangsung seumur hidup (Bangun \& Syahputra, 2017). Dalam Pendidikan jasmani siswa memiliki kesempatan untuk berperan serta dalam proses belajar melalui aktifitas jasmani, bermain dan berolahraga yang dilakukan secara sistematis, terarah, terencana, pembinnan dalam pendidikan jasmani digunakn sebagai bekal dalam kehidupan sehari hari, sekaligus membentuk gaya hidup sehat dan aktif (Nofriantoni, 2021).

Pembelajaran pendidikan jasmani di tingkat Sekolah Menengah Pertama (SMP), materi yang diberikan harus sesuai kurikulum yang ada. Dari berbagai materi pokok pendidikan jasmani yang ada di tingkat SMP salah satunya adalah tolak peluru. Tolak peluru adalah olahraga atletik nomor lempar yang bertujuan menolak atau mendorong satu bola yang terbuat dari besi atau logam yang dilakukan dari bahu dengan satu tangan dan di dorong mencapai jarak sejauh-jauhnya (Warsito, 2021). Dalam pembelajaran tersebut siswa dituntut harus menguasi berbagai macam teknik tolak peluru salah satunya adalah gaya Ortodoks. Untuk meningkatkan hasil pembelajaran tersebut guru tidak hanya mampu menguasi berbagai macam teknik tolak peluru dan juga mendemonstrasikan kepada siswa, namun juga harus berfikrir kreatif, memotivasi untuk meningkatkan pembelajaran.

Setelah dilakukan Observasi Pada pembelajaran tolak peluru gaya Ortodoks di MTs Terpadu AI Firdaus Kelas VII C, peneliti melihat masih banyak siswa yang belum mampu menguasi materi tersebut. Faktor yang menghambat peningkatan pembelajaran tolak peluru gaya Ortodoks, pada saat proses penyajian materi masih terlihat kurang menarik dan masih monoton, sehingga anak bosan, malas, dan kurang bersemangat dalam mengikuti pembelajaran yang sedang berlangsung. Keadaan semacam itu menjadikan masalah bagi guru pendidikan jasmani dalam melaksanakan pembelajaran Tolak peluru Gaya Ortodoks. Oleh sebab itu, dengan keadaan yang demikian maka tujuan pembelajaran Tolak peluru pasti belum dapat tercapai.

Dari permasalahan tersebut peneleliti mencoba membuat modifikasi bahan dasar pembuatan peluru dari besi diganti dengan abu kayu bakar yang nantinya dibuat bulat seperti tolak peluru pada umumnya, yang diharapkan bermanfaat dan mampu menarik perhatian siswa sehingga siswa semangat dan tidak bosan dalam mengikuti pembelajaran. Diaharapakan modifikasi peluru ini dapat meningkatkan keterampilan siswa dalam melakukan Gaya Ortodoks dan merubah situasi dari pembelajaran yang kurang diminati atau digemari oleh anak baik putra maupun putri, menjadi sangat digemari dan menyenangkan.

Berdasarkan uraian diatas maka peneliti bermaksud mengadakan penelitian yang berkaitan dengan Modifikasi Media Pembelajaran Untuk Meningkatkan Hasil Pembelajaran Tolak Peluru Gaya Ortodoks Pada Siswa Kelas VII C MTs Terpadu AI Firdaus Katikan iKedunggalar tahun pelajaran 2020/2021.

\section{Metode}

Jenis penelitian ini adalah penelitian tindakan kelas (PTK). Penelitian tindakan kelas adalah penelitian yang dilakukan oleh guru atau peneliti yang dilakukan dikelas dengan tujuan untuk mengumpulkan informasi berbabagai praktek yang dilakukan (Firmansyah, 2016). Penelitian ini meliputi observasi, dan tes hasil pembelajaran. Rancangan penelitian ini menggunakan dua siklus yang masingmasing memiliki empat tahapan yaitu:

1. Perencanaan

Rencana penelitian meruapakan langkahlangkah penelitian yang terstruktur dengan tujuan mengumpulkan data-data yang akurat (Pambudi et al., 2019)

2. Pelaksanaan

Pelaksanaan suatu bentuk proses kegiatan yang berawal dari rangkaian perencanaan yang mempunyai tujujan tertentu (Paryanto \& Wati, 2017)

3. Pengamatan

Pengamatan suatu tindakan yang di lakukan oleh guru atau peneliti yang menncari jawaban atas masalah yang akan dipecahkan (Hendri, 2020)

\section{Refleksi}

Refeleksi suatu kegiatan yang dilakukan dalam proses pembelajaran berupa penilaian tertulis maupun lisan oleh peserta didik (Mustafa \& Sugiharto, 2020)

Penelitian ini dilakukan di MTs Terpadu Al Firdaus Kedunggalar Kelas VII C dengan jumlah siswa 24 anak yang terdiri dari 9 anak laki-laki dan 15 anak perempuan. Penelitian ini dilaksanakan pada semester genap tahun ajaran 2020/2021 dilakukan selama 60 hari sejak 15 Januari 2021 sampai dengan 15 Maret 2021. Penelitian ini juga melibatkan kerjasama anatara wali murid dan khususnya guru 
Jurnal Edumaspul, 5 (2), Year 2021 - 526

(Sofyan Lutfi Aziz'1 Andy Widhiya Bayu Utomo²)

PJOK MTs Terpadu Al Firdaus. Adapun instrument penelitian ini dapat dilihat pada tabel berikut :

Tabel 1. Instrument Pengumpulan Data

\begin{tabular}{|c|c|c|}
\hline No & Jenis Data & Pelaksanaan \\
\hline 1 & Observasi & $\begin{array}{l}\text { Observasi dilakukan } \\
\text { terhadap siswa selama } \\
\text { proses pembelajaran, } \\
\text { mengamati siswa yang } \\
\text { melaksanakan } \\
\text { pembelajaran } \\
\text { berlangsung. }\end{array}$ \\
\hline 2 & Tes & $\begin{array}{l}\text { Tes dilakukan terhadap } \\
\text { siswa pada saat } \\
\text { pembelajaran, } \\
\text { mempraktekkan tolak } \\
\text { peluru dengan gaya } \\
\text { Ortodoks dengan } \\
\text { menggunakan Bola yang } \\
\text { terbuat dari Abu Kayu } \\
\text { Bakar. }\end{array}$ \\
\hline
\end{tabular}

Untuk keberhasilan atau tercapainya penelitian ini, yaitu apabila mendapatkan skor 75 yang sesuai dengan Kriteria Kelulusan Minimum (KKM). Untuk ketuntasan nilai siswa dapat dilihat pada tabel berikut ini :

Tabel 2. Rentang Skor Penilaian

\begin{tabular}{cccc}
\hline No. & Skor & Predikat & Kriteria \\
\hline 1. & $86-100$ & Sangat Baik & Tuntas \\
2. & $71-85$ & Baik & Tuntas \\
3. & $56-70$ & Cukup & Tidak Tuntas \\
4. & $\leq 50$ & Kurang & Tidak Tuntas \\
\hline
\end{tabular}

\section{Hasil dan Pembahasan}

Sebelum pelaksanaan penelelitian berlangsung, pada tahapan ini peneliti menyusun skenario pembelajaran yang terdiri dari (1) menganalisis kurikulum dan melihat kompetensi dasar yang akan disampaikan kepada peserta didik. (2) membuat Rencana Proses Pembelajaran (RPP) tolak prluru gaya Ortodoks sesuai dengan kurikulum 2013. (3) menyiapkan media pembelajaran tolak peluru gaya Ortodoks. (4) membuat lembar observasi dan penilaian pembelajaran tolak peluru gaya Ortodoks.

\section{Pelaksanaan Tindakan Siklus I}

Berdasarkan hasil Observasi pembelajaran pada siklus I, proses pembelajaran tolak peluru menggunakan media Bola Abu Kayu Bakar yang dilakukan oleh peneliti terhadap peserta didik telah mengalami peningkatan. Untuk lebih jelasnya dapat dilihat pada tabel berikut:

Tabel 3. Hasil Pembelajaran Siklus I

\begin{tabular}{|c|c|c|c|c|c|}
\hline $\begin{array}{c}\text { No } \\
\text {. }\end{array}$ & Skor & $\begin{array}{l}\text { Predik } \\
\text { at }\end{array}$ & $\begin{array}{c}\text { Kriteri } \\
\quad \text { a }\end{array}$ & $\begin{array}{c}\text { Jumla } \\
\text { h } \\
\text { Siswa }\end{array}$ & $\begin{array}{c}\text { Presentas } \\
\text { e }\end{array}$ \\
\hline 1. & $\begin{array}{l}86- \\
100\end{array}$ & $\begin{array}{c}\text { Sangat } \\
\text { Baik }\end{array}$ & Tuntas & - & - \\
\hline 2. & $\begin{array}{l}71- \\
85\end{array}$ & Baik & Tuntas & 11 & $45,8 \%$ \\
\hline 3. & $\begin{array}{l}56- \\
70\end{array}$ & Cukup & $\begin{array}{l}\text { Tidak } \\
\text { Tuntas }\end{array}$ & 10 & $41,6 \%$ \\
\hline 4. & $\leq 50$ & $\begin{array}{l}\text { Kurang } \\
\text { Jumlah }\end{array}$ & $\begin{array}{l}\text { Tidak } \\
\text { Tuntas }\end{array}$ & $\begin{array}{r}3 \\
24 \\
\end{array}$ & $\begin{array}{l}12,5 \% \\
100 \% \\
\end{array}$ \\
\hline
\end{tabular}

Dari data hasil belajar siswa pada siklus I, siswa yang tuntas dalam melaksanakan pembelajaran sebanyak 11 siswa (45,8\%), sedangkan yang tidak tuntas sebanyak 13 siswa (54,1\%). Dari data tersebut secara umum pelaksanaan pembelajaran tolak peluru gaya Ortodoks pada siklus I dinyatakan Belum Tuntas rata-rata siswa meperoleh nilai 68. Hasil tersebut masih jauh dari Kriterian Kelulusan Minimum yaitu 75, maka dari itu peneliti melanjutkan pada siklus II.

\section{Pelaksanaan Tindakan Siklus II}

Berdasarkan hasil pembelajaran siklus I sebelumnya, masih terdapat siswa yang belum tuntas melaksanakan pembelajaran tolak peluru gaya Ortodoks maka dari itu peneliti menindak lanjuti persemasalahan tersebut di siklus II. Pada siklus II siswa terlihat peningkatan yang sangat signifikan untuk lebih jelasnya dapat dilihat pada tabel berikut : Tabel 4. Pembelajaran Siklus II

\begin{tabular}{|c|c|c|c|c|c|}
\hline No & Skor & $\begin{array}{l}\text { Predik } \\
\text { at }\end{array}$ & $\begin{array}{c}\text { Kriteri } \\
\text { a }\end{array}$ & $\begin{array}{c}\text { Jumla } \\
\text { h } \\
\text { Siswa }\end{array}$ & $\begin{array}{c}\text { Presentas } \\
\text { e }\end{array}$ \\
\hline 1. & $\begin{array}{l}86- \\
100\end{array}$ & $\begin{array}{c}\text { Sangat } \\
\text { Baik }\end{array}$ & Tuntas & 10 & $41,6 \%$ \\
\hline 2. & $\begin{array}{l}71- \\
85\end{array}$ & Baik & Tuntas & 12 & $50 \%$ \\
\hline 3. & $\begin{array}{l}56- \\
70\end{array}$ & Cukup & $\begin{array}{l}\text { Tidak } \\
\text { Tuntas }\end{array}$ & 2 & $8,3 \%$ \\
\hline 4. & $\leq 50$ & $\begin{array}{l}\text { Kurang } \\
\text { lumlah }\end{array}$ & $\begin{array}{l}\text { Tidak } \\
\text { Tuntas }\end{array}$ & 24 & $100 \%$ \\
\hline
\end{tabular}

Dari data hasil belajar siswa pada siklus II, siswa yang tuntas dalam melaksanakan pembelajaran 
Jurnal Edumaspul, 5 (2), Year 2021- 527

(Sofyan Lutfi Aziz ${ }^{1}$, Andy Widhiya Bayu Utomo²)

sebanyak 22 siswa (91,6\%), sedangkan yang masih tidak tuntas sebanyak 2 siswa (8,3\%). Dari data tersebut secara umum pelaksanaan pembelajaran tolak peluru gaya Ortodoks pada siklus II dinyatakan Tuntas rata-rata siswa meperoleh nilai 80. Hasil tersebut sudah memenuhi Kriteria Kelulusan Minimun (KKM), hal ini sesuai yang diharapkan oleh peneliti. Maka dari itu peneliti memutuskan untuk mengentikan penelitian tersebut karena sudah memenuhi kriteria keberhasilan, walaupun masih ditemukan 2 siswa yang tidak memenuhi kriteria, peneliti melihat dua siswa tersebut memang kelebihannya bukan dibidang atletik nomor lempar. Peneliti mengharapkan guru PJOK MTs Terpadu Al Firdaus untuk memotivasi dan membimbing siswa tersebut.

\section{Simpulan}

Berdasarkan hasil penelitian pada siswa MTs Terpadu Al Firdaus Kedunggalar kelas VII C terhadap peningkatan hasil belajar tolak peluru gaya Ortodoks dengan menggunakan media Bola Abu Kayu Bakar terbukti terbukti dapat meningkatkan pembelajaran tolak peluru gaya Ortodoks, hal ini dibuktikan dari penelitian yang diperoleh dari siklus I dan siklus II, disamping itu siswa terlihat antusias dan semangat dalam mengikuti pembelajaran, dikarenakan media tersebut unik, ramah lingkungan, tidak terlalu berat, tidak monoton, dan aman bagi siswa atau tidak mencederai siswa. Peneliti berharap media ini dapat digunakan bagi guru-guru PJOK lainnya.

\section{Daftar Pustaka}

Asnaldi, A., FIK-UNP, Z., \& M, M. (2018). Hubungan Motivasi Olahraga Dan Kemampuan Motorik Dengan Hasil Belajar Pendidikan Jasmani Olahraga Dan Kesehatan Siswa Sekolah Dasar Negeri 16 Sintoga Kecamatan Sintuk Toboh Gadang Kabupaten Padang Pariaman. Jurnal MensSana, 3(2), 16 . https://doi.org/10.24036/jm.v3i2.75

Bangun, S. Y., \& Syahputra, I. (2017). Peningkatan hasil belajar tolak peluru melalui penerapan strategi pembelajaran resiprokal. Jurnal Pendidikan Jasmani Indonesia, 13(2), 65-71.

Fadlih, A. M. (2019). Minat dan Motivasi Peserta Didik Penyandang Disabilitas Ketunarunguan terhadap Mata Pelajaran Pendidikan Jasmani Kesehatan dan Olahraga. Musamus Journal of
Physical Education and Sport (MJPES), 2(01), 6876. https://doi.org/10.35724/mjpes.v2i01.2072

Firmansyah. (2016). Penerapan Teori Pembelajaran Kognitif dalam Pembelajaran Pendidikan Jasmani dan Kesehatan. Jurnal Pendidikan Olahraga, 5(2), 154-164. https://journal.ikippgriptk.ac.id/index.php/olah raga/article/view/383

Hendri, G. (2020). Motivasi Siswa Dalam Proses Pembelajaran Pendidikan Jasmani Olahraga Kesehatan Di SMAN 1 Padang Sago Padang Pariaman. Jurnal Patriot, 2, 171-181. http://patriot.ppj.unp.ac.id/index.php/patriot/ article/view/533

Warsito. (2021). Menggunakan Metode Pembelajaran Timbal Balik ( Reciprocal Teaching) Pada Siswa Kelas Xi Ips 5 Sma Negeri 1 Sulang Semester 1 Tahun Pelajaran 2019 / 2020. 7(1), 50-58.

Mustafa, P. S., \& Dwiyogo, W. D. (2020). Kurikulum Pendidikan Jasmani, Olahraga, dan Kesehatan di Indonesia Abad 21. JARTIKA Jurnal Riset Teknologi Dan Inovasi Pendidikan, 3(2), 422438. https://doi.org/10.36765/jartika.v3i2.268

Mustafa, P. S., \& Sugiharto, S. (2020). Keterampilan Motorik Pada Pendidikan Jasmani Meningkatkan Pembelajaran Gerak Seumur Hidup. Sporta Saintika, 5(2), 199-218. https://doi.org/10.24036/sporta.v5i2.133

Nofriantoni, N., \& Info, A. (2021). Peningkatan hasil belajar dalam pembelajaran tolak peluru melalui pendekatan metode bermain bola karet pada siswa. Jurnal Penelitian Guru Indonesia, 6(1), 1925. https://doi.org/10.29210/02765jpgi0005

Pambudi, M. I., Winarno, M., \& Dwiyogo, W. D. (2019). Perencanaan dan Pelaksanaan Pembelajaran Pendidikan Jasmani Olahraga Kesehatan. Jurnal Pendidikan Olahraga, Universitas Negeri Malang, 4(1), 110-116. http://journal.um.ac.id/index.php/jptpp/

Paryanto, R., \& Wati, I. D. P. (2013). Upaya Meningkatkan Kebugaran Jasmani Siswa Melalui Pendidikan Jasmani. Jurnal Pendidikan Dan Pembelajaran Untan, 2(5), 143-154. 